that the Small-mouthed Salamander "often" shares breeding ponds with Spotted Salamanders. Presumably this applies to United States populations as in Canada the Small-mouthed Salamander has been recorded only on Pelee Island where Spotted Salamanders apparently do not occur. But omitted from the Small-mouthed Salamander account is mention of its extensive hybridization with Blue-spotted Salamanders on Pelee Island although elsewhere the hybridization of Blue-spotted with Jefferson salamanders is recognized.

On the positive side, this book does have all the species we know in Canada to date with distributions, many interesting highlights, and very colourful pictures. These will be found useful by some casually interest- ed uncritical naturalists. However, it is no substitute for the many carefully researched and more comprehensive, within their more limited areas covered, provincial guides available for amphibians and reptiles.

\section{Literature Cited}

Bumstead, Pat E. 2003. Canadian skin and scales: A complete encyclopedia of Canadian amphibians and reptiles. Simply Wild Publications Inc., Calgary. Alberta. 161 pages.

Cook, F. R. 1984. Introduction to Canadian amphibians and reptiles. National Museum of Natural Sciences, National Museums of Canada. 200 pages.

FrancIS R. COOK

Emeritus Curator and Researcher, Canadian Museum of Nature, P.O. Box 3443, Station D, Ottawa, Ontario K1P 6P4 Canada

\title{
Guides and Reference to the (1) Snakes, (2) Crocodilians, Turtles, and Lizards (3) Amphibians, of Eastern and Central North America (North of Mexico)
}

By R. C. Bartlett and Patricia P. Bartlett. 2005 (1), 2006(2\&3). University Press of Florida, 15 NW 15th Street, Gainesville, Florida 32611.342 (1), 316 (2), 283 (3) pages. 29.95 USD each.

The Bartlett team has produced a number of earlier books: A Field Guide to Florida Reptiles, Reptiles and Amphibians of the Amazon: An Ecotourists Guide (2003), and Florida Snakes: A Guide to Their Identification and Habits (2003). R. D. Bartlett, veteran herpetoculturist/herpetologist, founder of the Reptilian Breeding and Research Institute, boasts over 40 years writing and photographing, including more than 500 articles in magazines such as The Tropical Fish Hobbyist, Reptiles, and Reptile and Amphibian. Patricia Bartlett, former director of the Fort Myers Historical Museum, is an editor and writer who, in addition to coauthoring 12 books with R.D.B., also wrote A Dictionary of Sharks.

In these present volumes, the Bartletts have broadened their horizons and compiled a herpetofauna reference in three volumes which cover the entire eastern and central United States and adjacent Canada from the Atlantic to the tier of mid-western states from North Dakota to Texas. However, their southern bias persists. Species which range far north of the U.S. border have only the southern portion of their Canadian range shown on the generally crude distribution maps which only casually outline Canada, with the northern potions of the Canadian-based range are often cut off. No Canadian-based authors are included in the references, despite the many that have studied species included, some even from U.S. populations as well as Canadian material.
Each book has a brief Species List, a Preface and Introduction to the group(s) included. The bulk of the texts are accounts arranged by family and within these by related groups of species, and then individual species accounts. The later includes English and Scientific name followed by sections on Toxicity/Disposition (Snakes), Abundance/Range, Habitat, Size, Identifying features, Voice (in crocodilians and frogs), and Similar Species, Comments, and Additional Subspecies. There is a rather eclectic selection here sometimes of subspecies far to the west of the limits set for the book. There is a distribution map (see comment above), and one or more colour photographs for each species (regrettably without localities or date), but usually of spectacular quality, and it here that the book shines, and wins a place on many shelves.

But why, aside from this, would any Canadian naturalist want these books on their shelf? They do include all the species in eastern Canada, as all of these range north into this country from the United States. These accounts are of reference value for depictions of appearance (many species pictured are different from the Canadian variants) and natural history (contrast from more southern habitats) of these species in areas adjacent to Canada and beyond.

Attractive as it is, it is primarily an add-on for Canadian naturalists unless they are travelling south, and for practical purposes there are now many Canadian and adjacent state guides to reptiles and amphibians combined in single volumes that will be more useful references for identifying our herpetofauna.

FRANCIS R. COOK

Emeritus Curator and Researcher, Canadian Museum of Nature, P.O. Box 3443, Station D, Ottawa, Ontario K1P 6P4 Canada 